\title{
Corruption and Bias Among Judges in Nigeria as Recorded in 2018 and 2019: A Dash of Hope of the Common Man
}

\author{
T.K.Adekunle. PhD, BL. \\ Senior Research Fellow, Institute of African Studies University of Ibadan, Nigeria \\ Hilary Nwaechefu. LL.M, LL.B, BL, \\ Doctoral Research Candidate, University of Ibadan. Lecturer Faculty of Law Redeemer's University Ede Osun \\ state Nigeria
}

\begin{abstract}
The judicial officers all over the world are expected to eschew bias and corruption in the discharge of their duties. This presupposes that a Judge should not manifest animosity, partiality, or hatred or favouritism or demand or accept any form of gratifications in any judicial proceedings. The primary objectives of this paper will therefore be to identify challenges posed by bias and corruption in the administration of justice in Nigeria and make recommendations towards addressing the identified challenges. This paper will approach the Issues of bias and corruption in judicial proceedings in Nigerian by reference to Internet sources, Newspaper publications, law text books and law reports. The findings in this paper are that the Nigerian Judicial officers, in spite of long legal trainings, seminars and workshops organized for them, in spite of taking oaths of office, are still caught up in the web of bias and corruption in the rulings and judgments they deliver. The findings in this paper, amongst others, is that despite the outcry and criticisms of bias and corruption levelled against the bench, the Nigeria Government and other stake holders have not done enough to checkmate the ugly trend of corruption among judicial officers.. Keywords: corruption, bias, fair hearing, judicial proceeding, Natural justice

DOI: $10.7176 / \mathrm{JLPG} / 82-02$

\section{Introduction}

The hue and cry of bias and corruption among judicial officers in the course of discharging their duties in Nigeria is a global issue, has become topical, important, and perhaps notorious depending on your point of view. Lawyers, Political scientists, religious bodies and Social Critics have shed varying opinions on issue of bias and corruption among judicial officers not only in the Nigeria justice dispensation bur globally. The Nigeria Apex court and the judicial regulatory authority, the National judicial council (NJC) have made pronouncements on the all-important subject of bias and corruption in the administration of justice. Many writers in the past and present notably: Oluyede $(1988)^{1}$, Malemi $(2008)^{2}$, Wade \& Forsyth $(1994)^{3}$ among others have dwelt on this subject matter of bias bias and corruption on the part of the judicial officers and the disregard for the rule of Natural justice. The constitution of the federal Republic of Nigeria, 1999 as amended, guaranteed fair hearing in judicial proceedings. Same is the position in the universal declaration of human right ${ }^{4}$. There is no doubt that, for there to exist fair hearing and justice, Judges must eschew animosity, partiality, hatred or manifest favoritism for or against a litigant in judicial proceedings. For bias and corruption to be avoided, the National Judicial Council (NJC) as a regulatory body on the activities of judicial officers in Nigeria has to maintain some degree of proactive actions by way of enforcement of high level of integrity and discipline in the bench. There is no doubt that a discussion of this nature will serve the immediate and future need for the advancement of the Nigerian legal jurisprudence.
\end{abstract}

\section{The rule against bias}

The rule presupposes that an Adjudicator should not conclude in his mind that an accused is guilty when he has not heard the case in details. To conclude that an accused is guilty even before the actual trial implies that the accused has been pre judged. This rule also suggests that a man cannot be a judge where he is a party to the case otherwise he will manifest bias no matter how slight. To avoid bias therefore, a Judge must not take side before hearing commences, otherwise the judge will beclouded with bias. In such event, an accused would not receive fair hearing.

\section{Meaning of bias}

In university of Calabar Vs Esiaga ${ }^{5}$, Court of Appeal in Nigeria defined bias as "inclination, bent, pre-disposition, or preconceived opinion, a predisposition to decide a cause or an issue in a certain way, which does have the mind

\footnotetext{
${ }^{1}$ Nigeria Administrative Law, university press limited

${ }^{2}$ Administrative Law, Princeton publishers, $3^{\text {rd }}$ edition

3 Administrative Law, oxford UK: Clarendon press

${ }^{4}$ Article 10

5 (1977) 4 NWLR (PL 502) 719
} 
perfectly open to conviction of mind, which sways judgment and renders a judge unable to exercises his functions impartially in a particular case. To be biased therefore would mean that the adjudicator has ill feelings against a party in a case, which made him not likely to weigh evidence adequately before reaching a decision”.

\section{Meaning of real likelihood of bias}

Per Ndoma -Egba, $\mathrm{JCA}^{1}$ has this to say concerning bias. "Bias or likelihood of bias covers a wide range of likelihood of circumstances. It may arise if a Judge either explicitly or impliedly indicates partisanship in cause or matter before or by expressing hostile opinion favourable to one party in the controversy he has a duty to settle or has unduly early expressing his view about the merit or demerit of a case committed to him for fair hearing and determination. This amounts to the prejudgment, rendering the judge inadequate in the probing minds and eyes of the public to proceed in hearing and determination on the controversy between the parties concerned on the merit' In Omoniyi v. Central School Board, ${ }^{2}$ the Court of Appeal in Nigeria said it meant "a substantial possibility of bias". "This may arise because of personal attitudes and relationship, employee and employer relationship, partisan, in relations to the issue at stake and a host of other circumstances from which inferences of a likelihood of bias may be drawn." In the celebrated earlier case of Alakija Vs Medical Disciplinary Committee ${ }^{3}$ it was established in evidence that the Registrar was the prosecutor and the Appellant proved that the Registrar was with the members of the Committee determining the fate of the Appellant, on the decision of removing the Appellant's name from the Medical Register. The Supreme Court of Nigeria held that the principle of natural justice had, owing to the Registrar remaining with the Committee during their deliberation, not been fully observed.

If there is likelihood of bias, it means that the rule of natural justice has been disregarded or thrown to the wind; any decision reached in such an unholy set up would not survive any appeal or judicial review instituted thereto.

\section{Situations that could suggest likelihood of bias}

i. Where personal animosities exist between the Judge and a party or the party's family; most likely the Judge would be biased.

ii. Personal association and friendship. If a judge belongs to a social club like the Peoples club of Nigeria, Lagos Tennis club, Lagos polo club, etc and it happens that the club has a case before the Judge or a member of the club has a case before the Judge or the mere fact that one person among the litigants is a personal friend to the Judge, such a Judge is likely to be biased in his judgments or rulings. The Judge after all is a human being and would have sympathy for his club members and friends and so would likely operate under bias. The Judge is not likely to be fair on the balance of scale. No wonder in Oni Odeyinka \& ors v. Otunbanjo ${ }^{4}$, the court of Appeal, Ibadan division in Nigeria held that the chairman of the Appeal Tribunal should have refrained from taking part in the appeal in view of his past involvement with the NCPN party- the party of the $1^{\text {st }}$ respondent in the interest of justice. Similarly Justice Thomas Naron was indicted by the National Judicial Council (NJC) when the NJC found that there were constant and regular voice calls and exchange of SMS between the Judge and one of the lead counsels during the Osun state in Nigeria Governorship Election Petitions' Tribunal that heard the petition of the then Action Congress (AC) governorship candidate, Rauf Aregbesola against the then Governor Olagunsoye Oyinlola. Further investigations showed that the call logs of Justice Narons's phone showed that he was in constant communication with Otunba Kunle Kalejaiye, a Senior Advocate of Nigeria (SAN) and lead counsel to the then governor, while the Judge presided over the election tribunal that would decide Mr. Oyinlola's fate. The Judge later dismissed the petitioner's claim and affirmed the declaration of the Independent National Electoral Commission (INEC) that Prince Oyinlola validly won the 2007 governorship election. Oyinlola was, however, later sacked by the Court of Appeal which declared his opponent, Rauf Aregbesola, the authentic winner of the election ${ }^{5}$

iii. $\quad$ Family relationship and ties: - where, for instance, the family of the wife of the Judge is party in a suit; most likely the wife would influence her husband. That is while a Judge must not hear a case where any of the parties has personal ties with him. In such situation, the Judge has foreknowledge or previous knowledge of the case. He can therefore not be said to be completely a neutral person or stranger to the case.

The interest which may disqualify a Judge from adjudication may be pecuniary or for favour. The difference in essence between the two is that, proof of any pecuniary interest in the subject matter of the case however small

\footnotetext{
${ }^{1}$ Denge v. Ndakwoji (1992) 1NWLR (pt. 216) p.234 paras B-D

2 (1988) 4 NWLR (pt 89) 449 at 451

3 (1959), 4 FSC 38

${ }^{4}$ (1998) 8 NWLR( pt 562), p. 425

${ }^{5}$ www.naij.com $25^{\text {th }}$ October 2017
} 
on the part of the Judge disqualifies him from adjudication. In the second class of bias, that is favour, there must be actual evidence upon which it can be based. This may be as a result of proven personal relationship of the Judge with one of the parties or to his having previously played a role whereby he cannot be expected to receive evidence in the case and decide the issue with open mind. ${ }^{1}$ It is not a hidden fact suspicious conduct led to the retirement of Justice Ufot Inyang (Abuja High Court Nigeria): Justice Inyang was retired over a judgment in which he ordered Federal Road Maintenance Agency (FERMA) in Nigeria to pay four hundred and sixty million Naira $(=\mathrm{N}=460 \mathrm{M})$ $(\$ 1,271,049$ to one Mr. Chukwuani in a dispute relating to a certain twenty seven million Naira $(=\mathrm{N}=27 \mathrm{M})(\$ 74$, $605.05)$ being unpaid sum of the contract. The speed with which the order was signed by the Judge, enrolled and executed despite a subsisting interlocutory injunction by the Appeal Court, Abuja Division, raised eyebrows. ${ }^{2}$

\section{Exceptions to the rule of bias}

i. Of a truth, the rule of natural justice forbids a person from hearing and determining a case in which he is either a party or interested in the outcome of the case or he has family ties or relationship with a party in the case. Nevertheless the Judge may still sit on the matter if the statute imposes the duty upon him. In the case of Franklyn Vs Minister of Town and Country Planning ${ }^{3}$, a minister's decision on a matter in which he ought not sit on by the rule of natural justice, was challenged so as to quash his decision on the ground that the minister sat on his own case; the Court of Appeal held that the minister was empowered by statute to hear that case.

ii. We should remember that equity help the vigilant and not the indolent. So a litigant who gets the wind that there is likelihood of bias against him, nevertheless surrendered himself to the whole trial willingly, cannot turn around and allege bias because the outcome of the case went against him. Such afterthought action would fail.

iii. Consider the incidence of necessity. Emergency connotes an unusual situation, as in a state of crisis or war, so that a person, who may not be qualified to adjudicate on a matter owing to bias, may validly do so due to the challenging situation.

\section{Corruption on the part of the Judges in Nigeria}

Of all the sources of bias in judicial proceedings, corruption is the worst in hierarchy. Corruption is defined thus: depravity, perversion, or taint; an impairment of integrity, virtue or moral principle; especially the impairment of public official's duties by bribery. ${ }^{4}$ The dictionary went further to state concerning corruption. 'The word Corruption indicates impurity or debasement and when found in the criminal law it means depravity or gross impropriety'. ${ }^{5}$

If a Judge had received gratifications or some form of inducement-money wise or otherwise from a party in a case pending before such a Judge, there is no gainsaying that the judgment to be delivered in such an unholy atmosphere will most likely be in favour of the party from whom the moral bankrupt Judge received the bribe. The money inducement had ab initio created bias, a prejudged position in the mind of the Judge. This is the danger inherent in bias and corruption. These twin words are the bane of Nigeria state. It posses more danger when it enters into judiciary, which is supposed to be the last hope of the common man. Unfortunately bias and corruption among the supposed umpires had led to disciplinary action and even dismissal of some judges in Nigeria as depicted authoritatively in this article.

\section{Application of the rule against bias in Nigeria courts}

Nigeria being a common law jurisdiction inherited both the common law and the doctrine of equity by reason of the received English laws and the doctrine of statute of general application. Our courts also observe immensely the two concept of natural justice to wit: Nemo Judex in Causa sua (one cannot be a Judge in one's own case) and the Audi Alteram Paterm (hear both sides of a case). Where the rule of Nemo Judex in Causa and Audi Alteram Paterm are disregarded, then bias has set in. The attitude of the Nigeria superior court has always been to quash a decision clothed with bias. In Obadara \& Vs Resident of Ibadan West District Grade D Customary Court, ${ }^{6}$ the Court held that the rule of Natural Justice and the rule against bias are applicable in Nigeria. It was therefore no wonder in Umenwa Vs Umenwa \& Anor ${ }^{7}$, a lawyer who had appeared in a case, later on became a Judge and purported to decide the dispute, was held to have descended into the arena. The whole decision to be reached by such a judge would be set aside.

\footnotetext{
${ }^{1}$ Justice Okpanachi v. Commissioner for works (1997) 6 NWLR (pt 509) p.482 ratio 5

2 ibid

3 (1947)1 All ER 612

${ }^{4}$ Black's Law dictionary Ninth Ed. Edited by Bryan A Garner. P.397

${ }^{5}$ Ibid

$\left.{ }^{6} 1964\right)$, ALL NLR 336 at 344,

7 (1987) 4NWLR (Pt 67) 407
} 
Corruption and bias are the enemies of the concept of natural justice and fair hearing. Interestingly, section $36(1)^{1}$ incorporated the rule of natural justice and fair hearing. Section 36(1) state; "In determination of civil rights and obligations, including any question or determination by or against any government or authority, a person shall be entitled to a fair hearing within a reasonable time by a court or other tribunal established by law, and constituted in such a manner to secure its independence and impartiality".

The above provision is a clear confirmation that Nigeria observes the rule of natural justice which also includes the avoidance of bias in any judicial proceedings. Corruption and bias erode judiciary independence and impartiality and renders a judge a nuisance and danger to the judicial arm of the government.

\section{The National Judicial Council (NJC) has sanctioned over 70 judges in five years. It was reported in the local news $^{2}$}

Sanctioning was a bold move which the judiciary made in cleansing itself of Jurists with questionable character. Below is but just fifteen (15) of such cleansing. The scope of this article will not accommodate elaborate write up. Suffice it to say the few instances reported will serve our purpose and become an eye opener to the level of corruption and bias among the judicial officers in Nigeria.

1. Justice Oluyinka Gbajabiamila (Lagos State High Court): He allegedly delivered judgment in a matter before him 22 months after written addresses were adopted and 35 months after the close of evidence in the suit. He was recommended for compulsory retirement from office. ${ }^{3}$

2. Justice Idris M. J. Evuti (Niger state High Court): Justices Evuti was found to have used three different dates of birth, such as September 15, 1950, April 10, 1953 and April 1, 1953. He was recommended for compulsory retirement. The National Judicial Council (NJC) also recommended to the Niger state government, Nigeria to deduct all salaries received by him from September, 2015 till date from his gratuity and remit same to the council that pays salaries of all judicial officers. ${ }^{4}$

3. Justice Tanko Yusuf Usman (Niger state High Court): Justice Usman was found to have falsified his age from June 27, 1950 to June 27, 1951. NJC did not recommend his compulsory retirement because it had already accepted his retirement with effect from March 1 2015. It, however, asked Niger state to deduct from the gratuity the salaries he received from June 2015 when he should have retired from the Bench. ${ }^{5}$

4. Justice Rita Ofili-Ajumogobia (Federal High Court, Illorin Division): Justice Ofili-Ajumogobia of the Federal High Court was barred from elevation to the appellate court for allegedly adjourning a pre-election matter severally until the termination of the life span of the Ogun state House of Assembly. She was subsequently transferred from Lagos, where she sat over the case, to Ilorin division. ${ }^{6}$

5. Justice Mohammed Yunusa (Federal High Court, Enugu division): Justice Yunusa was recommended for compulsory retirement for making orders restraining anti-graft agencies from investigating some persons, including a former aviation minister, Mrs. Stella Oduah. ${ }^{7}$

6. Justice Olamide Oloyede (Osun state High Court): Justice Oloyede was retired because of the petition she wrote to the Osun State House of Assembly, Governor Rauf Aregbesola and the failure to conduct herself in such a manner as to preserve the dignity of her office and impartiality and independence of the judiciary. ${ }^{8}$

7. Justice B.T Ebuta (Cross River state High Court): Justice Ebuta was recommended for immediate retirement following NJC's findings on the allegations of abuse of judicial power, suppression and illegal/forceful takeover of a property in Calabar as contained in the petition written against him by Dr Ekanem Cobham. ${ }^{9}$

8. Justices Charles Archibong: Justice Archibong was found to have dismissed the grievous charges against former Intercontinental Bank Managing Director, Dr. Erastus Akingbola without taking his plea. He also refused to release the Certified True Copy (CTC) of his ruling to the lawyers. NJC also found that there were glaring procedural irregularities which showed that Archibong did not have a full grasp of the law and procedure of the court. ${ }^{10}$

9. Justice Thomas Naron: In the case of Justice Naron, the NJC found that there were constant and regular voice calls and exchange of SMS between the judge and one of the lead counsels during the Osun Governorship Election Petitions' Tribunal that heard the petition of the then Action Congress (AC) governorship candidate, Rauf Aregbesola against the then Governor Olagunsoye Oyinlola. ${ }^{11}$ Call logs of Narons's phone showed that he was in

\footnotetext{
Constitution of the Federal Republic of Nigeria 1999 as amended 2011

www.naij.com $25^{\text {th }}$ October 2017, www.nigeria lawyer.com

${ }^{3}$ www.naij.com $25^{\text {th }}$ October 2017

${ }^{4}$ ibid

ibid

${ }^{6}$ ibid

www.naij.com $25^{\text {th }}$ October 2017

8 ibid

9 ibid

${ }^{0}$ ibid

${ }^{11}$ www.naij.com $25^{\text {th }}$ October 2017
} 
constant communication with Otunba Kunle Kalejaiye, a Senior Advocate of Nigeria (SAN) and lead counsel to the then governor, while the judge presided over the election tribunal that would decide Mr. Oyinlola's fate. He later dismissed the petitioner's claim and affirmed the declaration of the Independent National Electoral Commission (INEC) that Prince Oyinlola validly won the 2007 governorship election. Oyinlola was, however, later sacked by the Court of Appeal which declared his opponent and incumbent Governor, Rauf Aregbesola, the authentic winner of the election. ${ }^{1}$

The NJC said that Naron's action was contrary to the Code of Conduct for Judicial Officers under Section 292 (1) (b) of the 1999 Constitution of the Federal Republic of Nigeria as amended. ${ }^{2}$

10. Justice Abubakar Mahmud Talba (Federal Capital Territory (FCT) High Court): He was dismissed over the manner he handled the case of a convicted police 'pension thief', John Yakubu Yusuf. The council castigated Justice Talba for what it termed "unreasonable exercise of judicial discretion" in the case. Justice Talba was suspended for 12 months without pay. ${ }^{3}$

11. Justices Gladys Olotu (Federal High Court, Abuja): Justice Olotu was said to have breached laid down judicial procedure by delivering a judgment in a case 18 months after the final address by counsel contrary to the constitutional provisions that judgment should be delivered within a period of 90 days. ${ }^{4}$

12. Justice Ufot Inyang (Abuja High Court): Justice Inyang was retired over a judgment in which he ordered FERMA to pay four hundred and sixty million Naira $(=\mathrm{N}=460 \mathrm{M})(\$ 1,271,049)$ to Chukwuani in a dispute relating to a certain twenty seven million Naira $(=\mathrm{N}=27)(\$ 74,605.05)$ being unpaid sum of the contract. The speed with which the order was signed by the Judge, enrolled and executed despite a subsisting interlocutory injunction by the Appeal Court, Abuja Division, raised eyebrows. ${ }^{5}$

14. Justice Stanley Nnaji (Enugu High Court): He committed what amounted to judicial abuse of process when in a case that was clearly outside his jurisdiction, he ordered that Chris Ngige, the then governor of Anambra state Nigeira, should be removed from office. ${ }^{6}$

15. Justice Solomon Hunponu-Wusu, Lagos state deputy chief judge (Administration): He was recommended for retirement from the judiciary after the council investigated a petition by the Tourist Company of Nigeria Plc, which accused him of shady deals in the suit between it and another company. ${ }^{7}$

13. Justice Chudi Nwokorie (Federal High Court, Owerri): He was dismissed for breach of his oath of office and abuse of his powers, while Justice Wilson Egbo-Egbo, formerly of the Abuja High Court, and Justice Stanley Nnaji of the Enugu High Court were sacked for acts deemed by the NJC to have contravened their professional oath of office. $^{8}$

Others on the list of dismissed judges are: Justice Dahiru Saleh, Justice Wilson Egbo-Egbo, Justice Stanley Nnaji, Justice Chuka Jideofor Okoli, Justice Chudi Nwokorie and Justice Solomon Hunponu-Wusu, among others. ${ }^{9}$

Indictment of judges, lawyers in corruption cases dangerous, worrisome - Ekiti Chief Judge lamented ${ }^{10}$

Following the indictment of some judges and lawyers by the Department of State Services (DSS) for alleged corruption cases bordering on inducements by litigants, the Chief Judge of Ekiti State, Nigeria, Justice Ayodeji Daramola, has described the scenario as very dangerous to the fight against pilfering of public funds. Daramola said though cases of persecution against members of the bench and bar must have been suspected, members of the legal profession must be above board as ministers in the temple of justice, particularly when it comes to the issue of financial inducements. Some Judges of the Supreme Court, including Justices Sylvester Ngwuta and Inyang Okoro and Justice Ademola Adeniyi of the Federal High Court in Abuja, among others, were in October 2016 arrested by DSS for allegedly taking bribes and were subsequently arraigned in Court by the federal government. Daramola spoke in Ado in Ekiti state, at the commencement of the 2017 Law Week organized by the Nigerian Bar Association (NBA), Ado Ekiti Branch. He spoke on the topic: 'Corruption: Origin, Effect and Mechanism for Curtailment'.

The Chairman of the Branch, Barrister Gbenga Adaramola, refuted the widespread impression that lawyers were not committed to fighting grafts, saying the NBA national body recently disrobed 37 lawyers for corrupt practices.

The Chief Judge (CJ) asserted that as much as he holds unflagging belief that the legal profession should not be rubbished, he opined that people working in the temple of justice must shun any form of inducement as well.

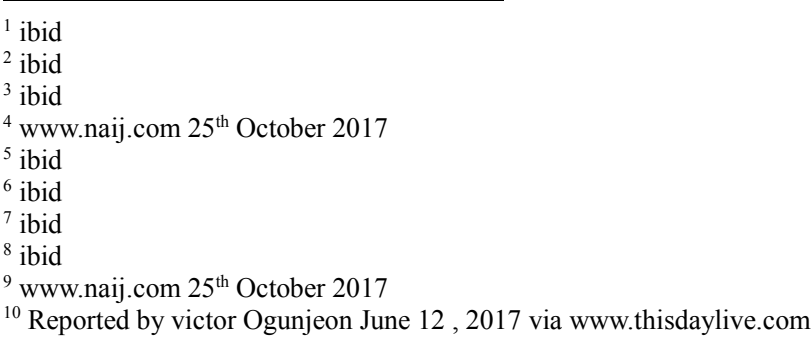


"In the last one year, the legal profession has been the butt of ridicule and jokes due mainly to exposure of involvement of judges and lawyers in corruption cases that were primarily geared to obstruct and pervert justice. Lawyers like Mafia Bookies and shacks, have become bagmen who now ferry bribes to Judges. It is almost impossibility for litigants to bribe judges without active involvement of lawyers. The bar and bench have become the focus of state agencies empowered by law to wage war against corruption. There have been insinuations in certain quarters on either ground or misguided belief that the executive is deliberately waging war against the judiciary. I rather don't believe that is the issue. As much as I believe there is no perfect institution in the world, for credibility sake, the Judges, like Ceaser's wife, must nevertheless be above board."1

The Chief Judge said that It was high time judicial officers understand that they cannot compete with politicians in wrongdoings, because that may put such officer to a point of no return, as politicians who committed similar offence may go to jail and come back to be elected or appointed. He stated that it was the corrupt activities of a few individuals among the Judges that had put a stigma on the whole judiciary. The Chief Judge noted that it would take many years for the Bench to clear the mess. Most certainly, he said, Nigeria's judicial system needs a thorough reappraisal.

The NBA boss added that the body was ready to protect the rights of every Nigerian by offering free legal services to poor Nigerians, describing this as the best way to give back to the society. ${ }^{2}$

As if the incidents of corruption already pointed out above was not enough to caution the judicial arm of the government of Nigeria, the third arm of the Nigerian government further received a blow of shame recently in January 2019, when allegation of high powered corruption was levelled against the Head of judiciary in Nigeria, the holder of the office of the Chief Justice of the federal Republic of Nigeria (CJN) in the person of Justice Walter Onnoghen. Justice Onnoghen was accused of false asset declaration by the Code of Conduct Bureau (CCB). The Executive Director, Anti-Corruption and Research Based Data Initiative, Mr. Dennis Aghanya had recently filed a petition at the Code of Conduct Tribunal against the Chief Justice of the federal Republic of Nigeria (CJN), accusing the CJN of false asset declaration and money laundering following the trace of millions of United states Dollars found in three of his domiciliary accounts with the Standard Chartered Bank plc; accounts numbers: 1062650,5001062686 and 5001062679 with a total balance of about three million US Dollars $(\$ 3 \mathrm{M}){ }^{3}$. These assets were reportedly kept secret by Justice Onnoghen. The Code of Conduct Tribunal is a tribunal with its headquarters in Abuja the Nigerian capital, charged with the responsibilities of trying the cases of corrupt public office holders. The Code of Conduct Tribunal's statement read in part: 'the Code of Conduct Tribunal has scheduled Monday, 14th January, 2019 for the commencement of the trial against current Chief Justice of Nigeria, Honourable Justice Onnoghen Nkanu Walter Samuel for alleged non-disclosure of asset ${ }^{4}$ '. Consequent upon this development, the federal government of Nigeria headed by President Munhammadu Buhari issued an executive order suspending the Chief Justice from office pending the outcome of his trial ${ }^{5}$.

It should be noted that Justice Walter Onnoghen who assumed office as the Chief Justice of the federal Republic of Nigeria (CJN) on $6^{\text {th }}$ March 2017 is being prosecuted for several financial impropriety. The point worthy of note here is, why would the judicial arm known all over the world as the last hope of the common man now turnout in Nigeria to be a bastion of corruption? The judiciary is supposed to be the proud bastion of justice and the institutional salvation of Nigeria and indeed every country ought to lie in the hand of the legal profession.

Following the wide spread corruption allegation against the Judges in Nigeria, the federal government had directed that the bank accounts of more Judges be place on surveillance and monitoring. ${ }^{6}$

\section{Recommendations towards minimizing the likelihood and incidence of bias and corruptions among Judges} and other adjudicators in Nigeria.

1. Names of proposed persons to be appointed to the Bench should be published in all the branches of the Nigeria Bar Association (NBA) so that every lawyer will have the opportunity of scrutinizing the integrity of the persons before final appointment.

2. We also recommend that quarterly questionnaire be distributed to members of every branch of the Nigeria Bar Association (NBA) so that National Judicial Council (NJC) will get feedback concerning any corrupt Judges early enough and then take necessary actions before it is too late.

3. A Judge appointed should be posted outside his own geo-political Zone. A Judge of Yoruba extraction should be posted to the south east, south or the Northern part of the Nigeria. By this arrangement, a Judge is not likely to come in contact with a litigant whom he knew personally appear before him in a case, wherewith he may become biased or bribed. It is still possible for the Judge to have persons he knew

\footnotetext{
${ }^{1}$ Reported by victor Ogunjeon (ibid)

${ }^{2}$ Reported by victor Ogunjeon (opcit)

${ }^{3}$ Punch newspaper, January13, 2019 at $\mathrm{p} 2$

${ }^{4}$ ibid

${ }^{5}$ Punch newspaper, January $26^{\text {th }}, 2019$ at $\mathrm{p} 2$

${ }^{6}$ Punch newspaper, January $27^{\text {th }}, 2019$ at p 2
} 
appear before him in a case even when he serves outside his geo-political Zone, but such coincidence is very slim and may rarely happen if a Judge does not serve in his geo-political Zone.

4. A serving Judge should be barred from membership of any social clubs or secret societies. If a serving Judge is a member of clubs like: the Peoples club of Nigeria, Lion Club, Rotary club, Lagos Tennis Club, Lagos Polo Club, Lagos country club etc, he is likely to be influenced by the members of these clubs, should the club or any of its members be involved in a case pending before the Judge. The Judge is likely to be biased because of allegiance he is required by the constitution or articles of such clubs or secret societies to show to the club and its members. The best thing is for Judges to stay clear of these clubs or societies if Judges are to truly be free from bias and corruption.

5. In matrimonial proceedings, a male and a female Judge should sit jointly to hear determine the case so that gender attachment does not influence the reasoning of a single Judge. This will ensure that the female Judge serves as a check against bias on his learned brother and vice versa at the bench in determining matrimonial cases because, in matrimonial proceedings, parties are of opposite gender.

6. Bank accounts of every judicial officer should be placed on surveillance and monitoring. Any new account opened and operated by a serving judicial officer must immediately be reported to the Department of State Security Services (SSS) in Nigeria, for surveillance update. On no account should a serving judicial officer maintain foreign accounts. If such accounts are discovered, the money therein should be forfeited to the federal government of Nigeria.

The National Judicial council (NJC) should and indeed every well-meaning member of the global community should reflect on these proposals and if they are holistically implemented, the question of rampant corruptions which had rocked the integrity of the judicial arm of the government in Nigeria between 2018 and 2019 will be greatly minimized. The legal profession ought to be the proud bastion of justice and one of our greatest convictions is that the institutional salvation and ablution of any nation lie in the hands of the legal profession. It ought to be so and all hands should be on deck to maintain the sanctity of the judiciary and with concerted efforts, success is assured. 